\title{
MORPHOMETRIC STUDIES OF THE NEUROPATHOLOGICAL CHANGES IN CHOREATIC DISEASES
}

\author{
H. LANGE, G. THÖRNER, A. HOPF and K. F. SCHRÖDER
}

C. and O. Vogt - Institute for Brain Research, University of Düsseldorf, D-4000 Düsseldorf (G.F.R.)

(Received 17 November, 1975)

SUMMARY

The striatum, pallidum and subthalamic nucleus were studied by combined morphometric methods in serial sections of 13 brains of normal adults and of 15 patients with choreatic diseases. In addition the volume of the hemispheres and of the cortex were measured. All data obtained were corrected by the shrinkage factor to represent fresh brain values.

In Huntington's chorea the pallidum was more severely affected than is commonly appreciated. The average volume reduction was of the same degree (lateral $-57 \%$, medial $-50 \%$ ) as that of the striatum $(-56 \%)$. The absolute number of nerve cells of the pallidum decreased in both segments by about $40 \%$. The reduction of the volume and of the number of nerve cells of the subthalamic nucleus was found to be about $25 \%$. The average volume of nerve cells was not reduced in the three subcortical nuclei studied. For the first time it has been shown that there is no increase in the absolute number of glial cells in the striatum. The increased numerical density of glial cells is caused by shrinkage. The loss of nerve cells of the pallidum and subthalamic nucleus is caused mainly by a primary process. Huntington's chorea is a multifocal process.

Morphometric data do not suggest that subchorea is a variant of Huntington's chorea.

Chorea minor is regarded as a multifocal process with varying affliction of the striatum, pallidum and subthalamic nucleus. An increase in the number of glial cells and, as a rule, a moderate loss of nerve cells were found in this disease.

INTRODUCTION

Since the last decade of the nineteenth century generations of investigators have studied the neuropathology of choreatic diseases. Some fundamental problems 
of the pathomorphology of chorea, however, are still unsolved. Studying the literature, one has the impression that descriptive neuropathology based on classical methods has made only minor contributions during the last decades.

Most authors (e.g. Bruyn 1968) are of the opinion that in Huntington's chorea the striatum is the main site of the pathological process in the basal ganglia and that the changes in the pallidum and subthalamic nucleus are only secondary. This opinion, however, seems to us to be insufficiently documented.

Sometimes it is extremely difficult to decide by microscopic observations if there is a loss of nerve cells in a certain area of the CNS. This is especially true of shrunken areas where the nerve cells may even be crowded together though their number is reduced. On the other hand gliosis is usually described in those shrunken structures despite the fact that the higher density of glial cells could also be caused by shrinkage without a real increase in the absolute number of glial cells. Considering these possible errors descriptions of low, moderate or severe changes in the number of nerve and glial cells, of correlations between pathological alterations in fibreconnected structures and conclusions on primary, secondary or transneuronal degenerations should be regarded with great reserve.

The aim of this study is to obtain objective data of the neuropathological changes in choreatic diseases. An analysis of these changes is only possible if certain morphometric methods are combined.

The determination of the volumes of subcortical nuclei as performed by Jungklaass and Orthner (1960) is an indispensable first step. However, an insight into the nature of the process, or a decision as to whether the changes are primary, secondary or transneuronal, cannot be obtained by this method. The numerical cell density is inconclusive in shrunken structures if the total volume of the subcortical nucleus is unknown. The same holds true of the volume cell density.

\section{MATERIAL}

Complete frontal serial sections of 13 brains of normal adults and of 15 patients with choreatic diseases have been studied. The brains were all prepared in the same way as described by Vogt (1940). They were fixed by immersion in formalin, embedded in paraffin, cut at a thickness of $20 \mu \mathrm{m}$ and stained by cresyl violet and the myelin method of Woelcke.

\section{Group 1: "Normal" cases}

Cases without any indication of brain disease in the history, clinical examination and autopsy findings. Regressive changes in the normal range have not been excluded in order to have a suitable comparative group to the aged choreatic cases. $1,604 \mathrm{~g}$.

1. A 100, 19 years, male, aspiration pneumonia, transverse cord lesion, brain weight in formalin $1,383 \mathrm{~g}$.

2. A 58, 24 years, male, exsanguination caused by stab of the lung, brain weight in formalin

3. A 85,30 years, female, fat embolism after traffic accident, brain weight in formalin $1,150 \mathrm{~g}$.

4. A 77, 37 years, male, decapitation, brain weight in formalin $1,468 \mathrm{~g}$.

5. A 61,38 years, male, uraemic coma, fresh brain weight $1,550 \mathrm{~g}$.

6. A 97,39 years, male, pulmonary embolism, brain weight in formalin $1,322 \mathrm{~g}$. 
7. A 74, 40 years, male, decapitation, brain weight in formalin $1,298 \mathrm{~g}$.

8. A 65,40 years, female, veronal poisoning, fresh brain weight $1,310 \mathrm{~g}$.

9. A 102, 41 years, female, circulatory collapse with uterine inertia post partum, brain weight in formalin $1,165 \mathrm{~g}$.

10. A 56,61 years, male, aspiration during an operation for laryngeal cancer, fresh brain weight $1,330 \mathrm{~g}$.

11. A 88,62 years, male, peritonitis caused by metastasizing carcinoma of the stomach, brain weight in formalin $1,380 \mathrm{~g}$.

12. A 64,84 years, male, pneumonia, fresh brain weight $1,400 \mathrm{~g}$.

13. A 76,99 years, female, pneumonia, brain weight in formalin $1,080 \mathrm{~g}$.

\section{Group 2: "Subchorea"}

According to C. and O. Vogt (1937) and B. Patzig (1939) a hereditary disease with slight involuntary movements and without progression over a long period of time.

1. C 15, 78 years, female. In her family Patzig found minimal and non-progressive choreiform movements. As a young girl C 15 was a fidget. She demonstrated slight involuntary movements during her whole life particularly in the hands and the face, and swinging of the upper part of her body. Later she suffered from pernicious anaemia with cord involvement. She was cachectic. Cause of death was heart and circulatory failure. Fresh brain weight $1,220 \mathrm{~g}$.

2. C 12, 89 years, female. Half-sister of C 15 . Generalized involuntary movements, swinging of the upper part of the body, in later years gripping and pulling movements, rigidity in the last decades of her life. At the age of 85 strokes with transient paresis and permanent confinement to bed. General atherosclerosis, cachexia, heart and circulatory failure. Fresh brain weight $1.015 \mathrm{~g}$.

\section{Group 3a: "Chorea minor"}

1. Ep 14, 11 years, male. At the age of 8 angina, endocarditis, and chorea minor of a few weeks duration. Cause of death was a recurrent endocarditis. Brain weight in formalin 1,417 g.

2. Bu 61,34 years, female. At the age of 19 chorea minor of nearly 1 year duration. With 28 years rheumatic fever. One year later cardiac insufficiency. In the same year sudden headache and somnolence. At the age of $30 \frac{1}{2}$ postencephalitic Parkinsonism with akinesia, rigor and tremor. Cause of death was pellagra. Fresh brain weight $1,176 \mathrm{~g}$.

3. Bu 82, 54 years, female. At the age of 7 severe chorea minor. Endocarditis at the age of 20 , valvular defect. With 52 years complete heart block, later Adams-Stokes syndrome. Cause of death was heart insufficiency. Brain weight in formalin $1,410 \mathrm{~g}$.

4. Bu 94, 57 years, female. Debility. Chorea minor at the age of 6,2 relapses, the last at the age of 15. Valvular defect. Cause of death was circulatory and cardiac insufficiency. Fresh brain weight $1,020 \mathrm{~g}$.

5. Bu 11, 64 years, female. Chorea minor at the age of 16 . Onset of schizophrenia with hallucinations and catatonic symptoms at the age of 33, permanent hospitalisation. Death caused by myocardial infarction; general arteriosclerosis with coronary sclerosis. Fresh brain weight $1,242 \mathrm{~g}$. This case will be evaluated separately because of foci of vascular softening in the striatum on both sides.

\section{Group 3b: "Chorea gravidarum"}

Gr 3, 29 years, female. Hyperemesis beginning in the third month of pregnancy, lasting for 6 weeks with necessity for artificial feeding. Then, in the middle of the fourth month severe choreoathetotic movements, state of confusion. Death 10 days later caused by cardiac insufficiency. Brain weight in formalin $1,113 \mathrm{~g}$.

\section{Group 4: "Atypical chorea"}

Under this heading Patzig (1939) described cases of progressive chorea where no relatives with chorea could be detected despite extensive genealogical studies. C. and O. Vogt (1937) have published the following case as praechorea and Hopf (1952) as a special form of chorea.

Bu 42, 19 years, female. Debility, choreiform movements since her early childhood. Two epileptic seizures at the age of $12 ; 2$ months before her death increasing choreatic hyperkinesis and agitation. During the last days of her life fever and 5 generalized convulsions. Bronchopneumonia. Fresh brain weight $1,100 \mathrm{~g}$.

1. C 35, 40 years, female. One brother Huntington's chorea. Onset of choreiform movements, 
preferentially in the arms and the face at the age of 32 ; later disturbed articulation. At the age of 40 demented and temporarily confused, no rigidity. Peunomnia, cachexia, circulatory failure. Fresh brain weight $948 \mathrm{~g}$.

2. C 47, 41 years, female. Mother "restless". Mother's sister had convulsions. Onset of choreatic movements at the age of 28, disturbed articulation. Permanent hospitalisation since the age of 34. Increasing hyperkinesis, muscles always hypotonic, later paranoid psychosis and dementia. Severe cachexia, pneumonia. Fresh brain weight $956 \mathrm{~g}$.

3. C 50, 48 years, female. Mother had Huntington's chorea, onset at the age of 30 , death at 50 . The child of the patient is mentally defective, fidgety, grimaces. At the age of 33 first choreatic movements after endometritis post partum; muscles always hypotonic. At the age of 46 disturbed articulation, dementia. Pulmonary embolism. Fresh brain weight $1,056 \mathrm{~g}$.

4. C 14, 55 years, female. Father and brother Huntington's chorea. Onset of chorea at the age of 39. Permanent hospitalisation at the age of 49. Demented, dysarthric, increasing but not extreme rigidity, muscles of the hand hypotonic, however. Severe cachexia, bronchopneumonia. Fresh brain weight $872 \mathrm{~g}$.

5. C 45,56 years, male. Grandmother Huntington's chorea at the age of 59 , mother at the age of 51. Wife chorea gravidarum in all 7 pregnancies, 3 of 4 children had chorea minor, one of them with relapses and later Huntington's chorea at the age of 22. Onset of Huntington's chorea at the age of 41 , muscles hypotonic, severe disturbance of articulation, dipsomania, states of agitation; dementia at the age of 54 , severe cachexia. Fresh brain weight $1,117 \mathrm{~g}$.

6. C 32, 72 years, female. Father "twitches", one brother died in psychiatric hospital, the other brother is father of C 35 (Case 1 of Huntington group). Onset of chorea at the age of 54, slow progression. Admission to hospital at the age of 67. Carcinoma of the breast. Fresh brain weight $950 \mathrm{~g}$.

\section{METHODS}

The following parameters have been determined: Brain weight - Length, width, and height of the hemispheres before and after preparation - Volumes of the serial sections of the hemispheres, cortex, striatum, pallidum laterale and mediale, subthalamic nucleus - Numerical and volumetric densities of nerve cells in striatum, pallidum und subthalamic nucleus - Numerical and volumetric densities of glial cells in pallidum and striatum - Volume density of glial cell nuclei in pallidum Length and width of nerve cells in striatum and subthalamic nucleus and of nerve cell nuclei in subthalamic nucleus.

From these data the following parameters could be calculated: Shrinkage Fresh and relative volumes - Absolute numbers of nerve and glial cells - Glial index - Absolute fresh volumes of nerve and glial cells - Average volumes of nerve and glial cells - Rotation ellipsoid volumes of nerve cells and of their nuclei.

The methods used as well as the normal data have been described in detail in previous papers (Lange and Thörner 1974; striatum: Schröder, Hopf, Lange and Thörner 1975; pallidum: Thörner, Lange and Hopf 1975; subthalamic nucleus: Lange, Thörner and Hopf 1976) so that only a short description will be given in this paper.

\section{Swelling and shrinkage}

Changes in volume and weight occur at all stages of preparation and they vary from individual to individual even if the methods are standardized (Stephan 1960; Blinkov and Glezer 1968; Kretschmann and Wingert 1969; Schröder et al. 1975). The shrinkage factor was determined in two ways: first by comparing the brain weight 
- taking the specific weight into consideration - and the volume of the serial sections; secondly by comparing the linear dimensions of the hemispheres in formalin and in serial sections. The results of these 2 methods were combined to determine the shrinkage factor.

\section{Volumes of serial sections and fresh volumes}

The volumes of hemispheres, cortex, striatum (without fundus striati), pallidum, and subthalamic nucleus were calculated by measuring the corresponding planes of the serial sections (on enlarged photographs) with the aid of an electronic planimeter and by multiplying the values obtained by the distance between the sections. The fresh volume is the product of the volume in serial sections and the shrinkage factor.

\section{Numerical cell density}

i.e. the number of cells per volume unit of tissue, here per $\mathrm{mm}^{3}$. Depending on the density of cells $100-300$ counting grids were evaluated at a magnification of 375 . Only nerve cells with a nucleolus were counted in order to avoid correction formulae (Haug 1967). By counting all nerve cells the values would be too high because large cells may be cut 2 or even 3 times. A comparison of the numerical cell densities of various individuals is possible only if the values are corrected by the shrinkage factor which shows considerable interindividual variation.

\section{Glial index}

i.e. the number of glial cells per nerve cell or the quotient numerical glial cell density/numerical nerve cell density.

Absolute number of cells

The result of multiplying the numerical cell density by the volume of a subcortical nucleus is its absolute number of cells. This value is of great importance and is directly comparable to other values of the same and of other individuals.

\section{Volumetric nerve cell density}

i.e. the relative volume (in percent) occupied by nerve cell bodies in a given tissue. The volume cell density is determined by an integral method called the hitpoint method by Haug (1955). The number of "hit-points" covered by the structures to be determined (nerve cell bodies) within a test area is compared to the total number of points of a counting grid. Since points on a plane and not in a volume are to be evaluated the depth of focus has to be less than $1 \mu \mathrm{m}$. For this reason a high power objective (aperture 1.25) and a total enlargement of 1,687.5 was used, resulting in a depth of focus of $0.807 \mu \mathrm{m}$. One thousand test areas had to be evaluated in each hemisphere because of the low volume density of the widely scattered nerve cells in the pallidum.

\section{Volumetric density of glial cell nuclei}

In contrast to the nerve calls only the volume density of the nuclei of the glial 
cells was determined since the borders of the glial cell bodies are not distinct enough in cresyl violet stained sections.

\section{Statistics}

The statistical evaluation was carried out by a Siemens 4004 computer with plotter in the computer center of the University of Düsseldorf, using BMD programs (biomedical data - health science computing facility UCLA) for correlations and graphs, including histograms. For additional calculations a Diehl algotronic computer was used. For each of the above-described groups the mean, the standard deviation, the standard error of mean and the $95 \%$-confidence interval were calculated, separately for both sexes. The means of groups 2, 3, 4 and 5 were compared to the means of group 1 ; the $t$-test was applied to check for significance.

Stochastic correlations were tested by calculation of the correlation coefficient and the linear regression: $y=\left(a \pm s_{\mathrm{a}}\right)+\left(b \pm s_{\mathrm{b}}\right) x$ and $x=\left(a^{\prime} \pm s_{\mathrm{a}^{\prime}}\right)+\left(b^{\prime} \pm s_{\mathrm{b}^{\prime}}\right) y$ together with its $95 \%$-confidence interval.

Fig. 1 shows the morphometric equipment.

\section{RESULTS}

Brain weight, fresh volumes of hemispheres and of cortex

Only the group of patients with Huntington's chorea showed statistically significant lower values of these 3 parameters. The average brain weight in the control group was $1,415 \pm 81 \mathrm{~g}(\bar{x} \pm 95 \%$ confidence interval) for males and $1,176 \pm 154 \mathrm{~g}$ for females; in the Huntington group $1,117 \mathrm{~g}$ for males $(-21 \%)$ and $956 \mathrm{~g}$ for females $\left(-19 \%{ }^{* *}\right)$. The mean fresh volume of hemisphere amounted to $543 \pm 31 \mathrm{~cm}^{3}$ in normal males and $458 \pm 91 \mathrm{~cm}^{3}$ in normal females; in Huntington males $427 \mathrm{~cm}^{3}$ $(-21 \%)$ and in females $366 \mathrm{~cm}^{3}(-20 \% * *)$. The mean of the fresh volume of the cortex

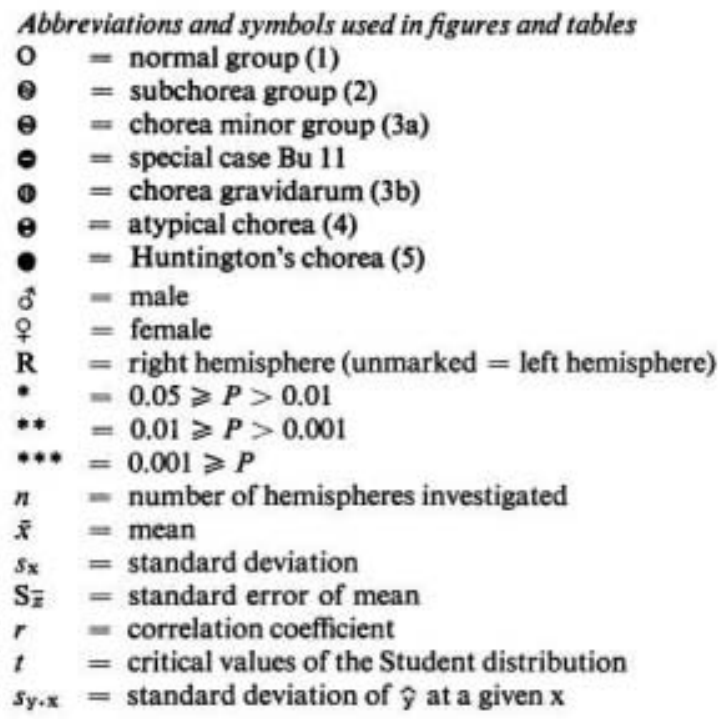




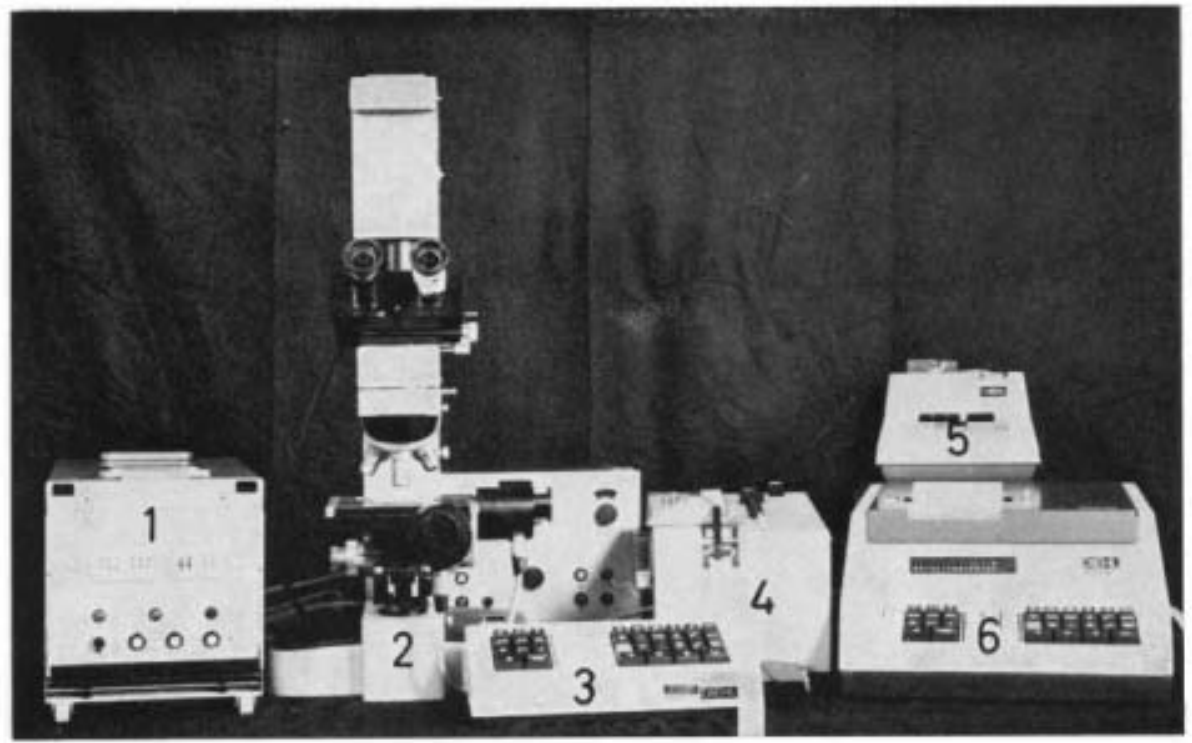

Fig. 1. Microscope and data processing equipment. 1: steering unit of the scanning stage; 2 : LeitzOrthoplan with automatic camera and motor stage; 3 : external keyboard (data input); 4 : paper tape puncher; 5 : paper tape reader; 6 ; table-top computer.

was found to be $273 \pm 27 \mathrm{~cm}^{3}$ in normal males and $235 \pm 37 \mathrm{~cm}^{3}$ in normal females; $219 \mathrm{~cm}^{3}$ in males $(-20 \%)$ and $190 \mathrm{~cm}^{3}$ in females $\left(-19 \%{ }^{* *}\right)$ of the Huntington group. There was a strong correlation of the volumes of the hemispheres and of the cortex in normal cases as well as in choreatic cases (Fig. 2).

\section{Striatum}

The fresh volume of the striatum was significantly reduced in the group of Huntington's chorea cases only (Table 1$)$. The mean values $( \pm 95 \%$ confidence interval) of the normal group were $10.2 \pm 3 \mathrm{~cm}^{3}$ for males and $9.0 \pm 0.5 \mathrm{~cm}^{3}$ for females, of the Huntington group $3.9 \mathrm{~cm}^{3}$ for males $(-62 \%)$ and $4.0 \mathrm{~cm}^{3}$ for females $(-58 \% * *)$. The highest degrees of shrinkage were found in cases with a low age of death. The volumes of the caudate nucleus and of the putamen were strongly correlated in the choreatic diseases as well (Fig. 3). That means that the degree of involvement of these 2 parts of the striatum was not different. The mean volume of the numerical density of the small nerve cells - corrected by the shrinkage factor - of the subchorea group (2) was not different from that of the normal group (1) (Table 2). In the chorea minor group (3), including the special case Bu 11, the density was $15 \%$ * and in the atypical chorea (4) $29 \%$ lower. The mean value of the Huntington group (5) was lowered by $36 \% * * *$.

The numerical density of the large nerve cells (Table 2) was not reduced but was increased in the choreatic groups in sufficiently good correlation with the degree of shrinkage of the striatum. Precise statements cannot be given as there was a great 


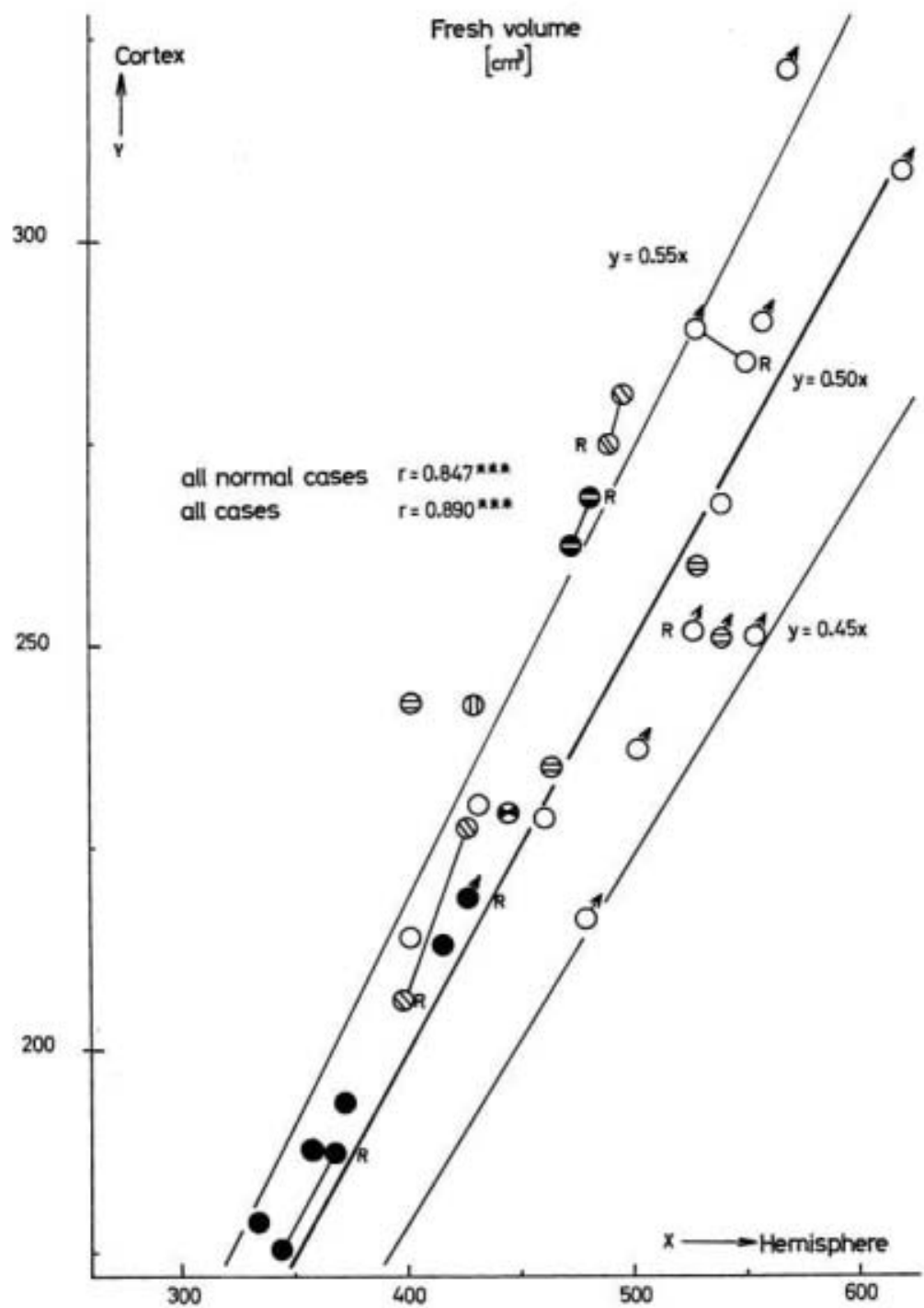

Fig. 2. Correlations of the fresh volumes of cortex and hemispheres in normal cases and in chorea. For explanation of symbols see page 406 .

variation of the values due to the insufficient number of counts in relation to these widely scattered elements.

The ratio of small to large nerve cells changed in the chorea groups (Table 2).

The absolute number of small nerve cells (Table 3 ) in the Huntington group was more reduced $(\hat{\sigma}-81 \%, q-70 \% * *)$ than the numerical density $(\hat{o}-50 \%$, ㅇ $-36 \%$ ) because of the pathological volume reduction (shrinkage) of the striatum. The lower values of the chorea minor group $\left(\sigma^{+}-6 \%\right.$, 으 $\left.-19 \%\right)$ were not statistically significant. The reductions in the special case $\mathrm{Bu} 11$ and in the case of atypical chorea were $50 \%$ and $70 \%$ respectively. 


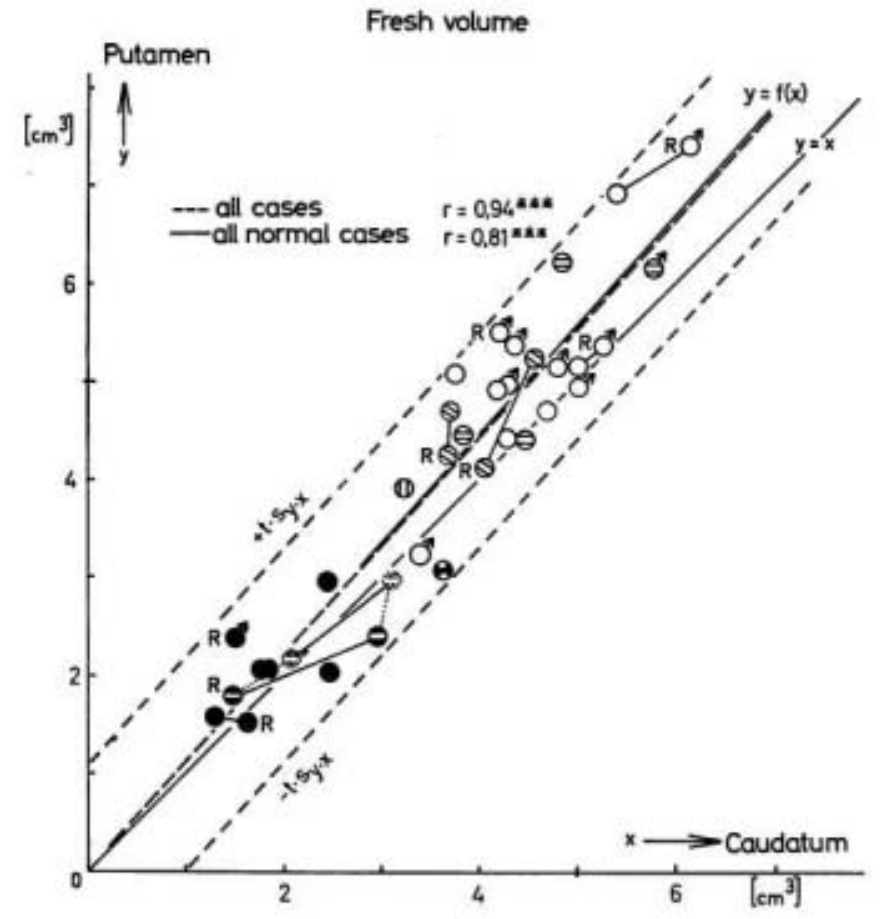

Fig. 3. Correlations of the fresh volumes of the caudate nucleus and putamen in normal cases and in chorea. For explanation of symbols see page 406.

The absolute number of large nerve cells was not significantly altered in the choreatic diseases studied.

The volumetric nerve cell density showed a relatively wide range of variation in normal brains $(3.08-4.67 \%)$, the mean value being $4.06 \% \pm 0.55 \%$. This means that about $4 \%$ of the striatum volume was occupied by nerve cell bodies. This volumetric nerve cell density was reduced in the choreatic groups, the difference being statistically significant only in the Huntington group $\left(-28 \% \%^{* * *}\right)$ and in the chorea minor group $\left(-20 \%{ }^{* *}\right)$ (Table 4$)$.

The corrected absolute volume of nerve cells - that is the total volume of all nerve cells in the striatum - was more reduced than the volumetric nerve cell density because of the shrinkage of the striatum (Table 5). The reduction was calculated to be $22 \% * *$ in the chorea minor and $68 \% * * *$ in the Huntington group.

The average diameter of the small nerve cell nuclei was $8.64 \mu \mathrm{m}\left(s_{\mathrm{x}} 0.34, \mathrm{~s}_{\overline{\mathrm{x}}} 0.11\right)$ in normal males and $8.70\left(s_{\mathrm{x}} 0.09, s_{\overline{\mathrm{x}}} 0.04\right)$ in normal females. It was reduced by $11 \% \%^{* * *}$ in the chorea minor and by $20 \% * * *$ in the Huntington chorea group.

The numerical density of glial cells was $41,100 \pm 3000 / \mathrm{mm}^{3}$ in the normal group (Table 6). From the increased numerical glial cell density of choreatic diseases (Table 6) erroneous conclusions have been drawn previously because the shrinkage of the striatum was not taken into consideration.

The absolute number of glial cells only should be the basis for further conclusions. 
It was 30\%* higher in the subchorea and $17 \%$ higher in the chorea minor group. The females of the Huntington chorea group had a decrease of $19 \%$, the male case had $48 \%$ fewer glial cells (Table 3 ).

The glial index - that is the number of glial cells per nerve cell - was increased in all chorea groups (Table 6).

\section{Pallidum}

All parameters were determined separately for pallidum laterale and mediale.

The fresh volume of the pallidum laterale was about $2 \frac{1}{2}$ times larger than that of the pallidum mediale. The fresh volumes of both segments of the pallidum were highly reduced in the special case Bu 11 and significantly in the Huntington group (Table 7).

The numerical nerve cell density was decreased by $18 \%$ in the pallidum laterale and by $20 \%$ in the pallidum mediale of the chorea minor group, the differences not being statistically significant (Table 8 ). In the group of Huntington's chorea an increase of $42 \% * *$ (lateral) and $27 \% *$ (medial) was found.

The absolute number of nerve cells, which is a more valuable and conclusive parameter, was reduced in the chorea groups, but significantly only in the Huntington group (Table 9).

The volumetric nerve cell density was $32 \% * *$ lower in the pallidum mediale of the chorea minor group. It was $50 \%{ }^{*}$ higher in the pallidum laterale and $32 \%{ }^{*}$ higher in the pallidum mediale of the Huntington group (Table 10). This increase, however, was due to the shrinkage of the pallidum.

The absolute volume of the total of nerve cells was reduced in the chorea groups (Table 11).

The average volume of nerve cells decreased only in the pallidum laterale of the atypical chorea $\left(6600 \mu \mathrm{m}^{3}\right)$, the normal value being $8,100 \mu \mathrm{m}^{3} \pm 1,060$. In the chorea minor group the slight decrease $\left(7,100 \mu \mathrm{m}^{3} \pm 248\right)$ in the pallidum laterale was insignificant and in the Huntington group the mean value $\left(8,100 \mu \mathrm{m}^{3}\right)$ was the same as in the normal group.

In the pallidum mediale the mean value of the normal group was $9,600 \mu \mathrm{m}^{3} \pm$ 1,280 , of the chorea minor group $8,200 \mu \mathrm{m}^{3} \pm 1,270$, and of the Huntington group $9,900 \mu \mathrm{m}^{3} \pm 1,330$.

The numerical density of glial cells was increased $(+44 \% * *$ lateral, $+31 \% * *$ medial) in the subchorea group and much more in the Huntington group $(+123 * * *$ lateral, $+83 \%^{* * *}$ medial) (Table 12). A statistically significant increase in the absolute number of glial cells did not exist (Table 13).

The volumetric density of glial nuclei in the pallidum laterale was higher in the chorea groups compared to the normal group (Table 14). In the pallidum mediale there were no significant changes.

The absolute volume of the total of glial nuclei in the pallidum was decreased in the Huntington group and in Bu 11 by about $20 \%$ in the lateral group and $40 \%$ in the medial respectively (Table 15).

This decrease holds true of the average volume of glial nuclei as well (Table 16). 
Absolute number of nerve cells

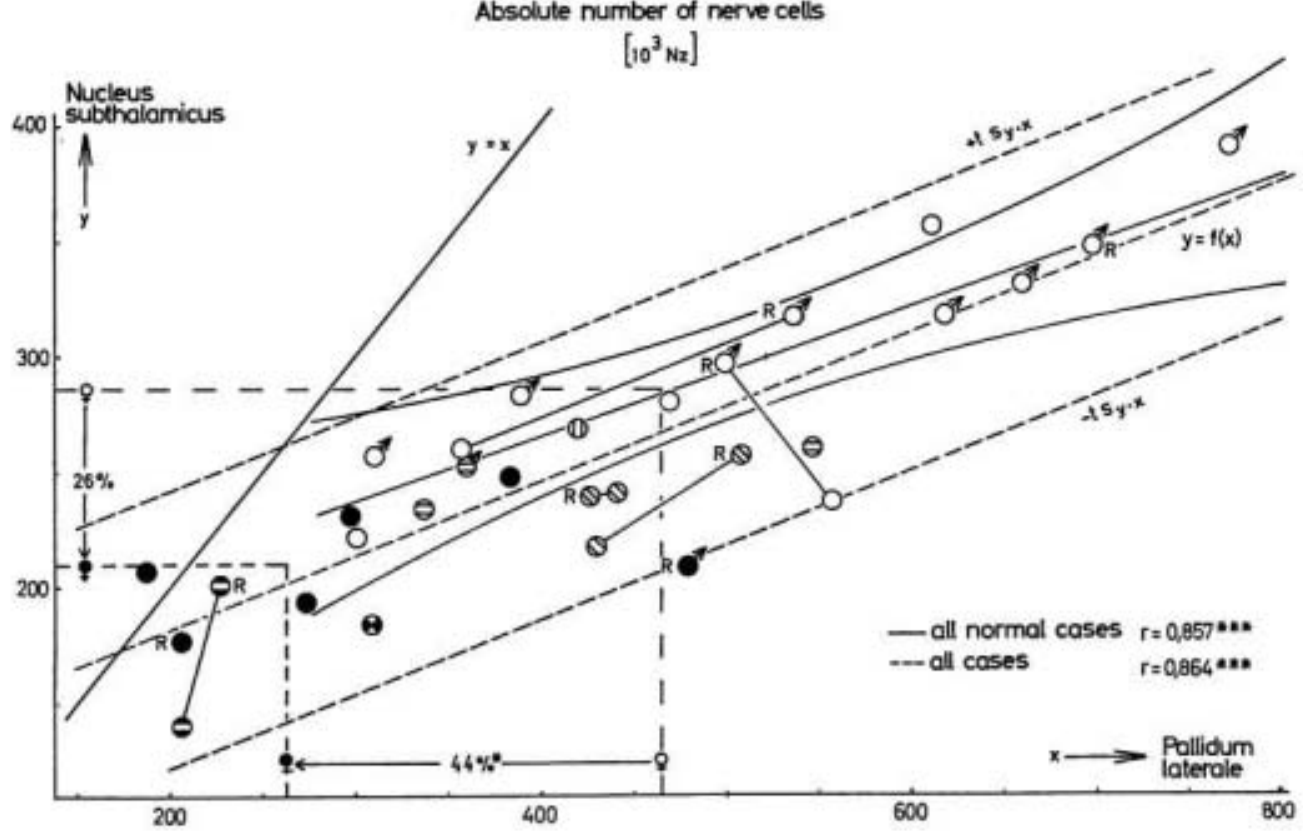

Fig. 4. Correlations of the absolute number of nerve cells in the pallidum laterale and subthalamic nucleus in normal cases and in chorea. For explanation of symbols see page 406.

The glial index, i.e. the ratio of glial cells/nerve cell increased in all chorea groups though the difference was not always statistically significant (Table 17).

\section{Subthalamic nucleus}

This nucleus consists of a lateral and a medial part, the latter having smaller nerve cells which are more densely arranged. There is no distinct border between these two parts, due to a gradual transition from lateral to medial.

The fresh volume was reduced in all chorea groups but in the subchorea and chorea minor cases the reduction was statistically insignificant (Table 18).

The numerical nerve cell density was only very slightly and insignificantly lower in the chorea groups. The normal values show considerable variations with mean values of $1,970 \pm 145$ nerve cells $/ \mathrm{mm}^{3}$ in the lateral and $2,910 \pm 330$ nerve cells/ $\mathrm{mm}^{3}$ in the medial part.

The absolute number of nerve cells was decreased in all chorea groups, in the subchorea and chorea minor, however, only very slightly (Table 18). The Huntington cases with the lowest death age had the lowest values.

The volumetric nerve cell density was not significantly altered in the chorea groups. The normal values were in the lateral part $1.58 \pm 0.15 \%$ and in the medial part $2.00 \pm 0.16 \%$.

The absolute volume of the total of nerve cells was lower in all chorea groups 
TABLE 1

STRIATUM - FRESH VOLUME $\left(\mathrm{cm}^{3}\right)$

\begin{tabular}{|c|c|c|c|c|c|c|c|c|c|}
\hline \multirow{2}{*}{$\begin{array}{l}\text { Case group } \\
\text { (see text) }\end{array}$} & \multicolumn{2}{|l|}{1} & \multirow{2}{*}{$\begin{array}{l}2 \\
9\end{array}$} & \multicolumn{2}{|l|}{3} & \multirow{2}{*}{$\begin{array}{l}\text { Bu } 11 \\
\text { 아 }\end{array}$} & \multirow{2}{*}{$\begin{array}{l}4 \\
q\end{array}$} & \multicolumn{2}{|l|}{5} \\
\hline & $\delta$ & ㅇ & & $\delta$ & q & & & $\delta$ & q \\
\hline$n$ & 10 & 4 & 4 & 1 & 4 & 2 & 1 & 1 & 6 \\
\hline$\hat{x}$ & 10.2 & 9.0 & 8.6 & 11.9 & 8.8 & 4.3 & 6.8 & 3.9 & 4.0 \\
\hline $\begin{array}{l}s_{\mathrm{x}} \\
\% \text { difference }\end{array}$ & 1.9 & 0.4 & 0.9 & - & 1.7 & - & - & - & 0.9 \\
\hline to group 1 & & & -4 & +17 & -2 & -52 & -24 & -62 & $-58 * *$ \\
\hline
\end{tabular}

TABLE 2

STRIATUM - NUMERICAL DENSITY $\left(\right.$ cells $\left./ \mathrm{mm}^{3}\right)$

\begin{tabular}{|c|c|c|c|c|c|c|}
\hline Case group & 1 & 2 & 3 & Bu 11 & 4 & 5 \\
\hline \multicolumn{7}{|c|}{ (a) Small nerve cells } \\
\hline$n$ & 14 & 2 & 4 & 1 & 1 & 6 \\
\hline $\bar{x}$ & 11090 & 10930 & 9620 & 9440 & 7890 & 7110 \\
\hline $5 x$ & 1170 & 1680 & 1160 & - & - & 1450 \\
\hline $\begin{array}{l}\% \text { difference } \\
\text { to group } 1\end{array}$ & & -7 & $-15^{*}$ & -15 & -29 & $-36 * * *$ \\
\hline \multicolumn{7}{|c|}{ (b) Large nerve cells } \\
\hline $\bar{x}$ & 65 & 108 & 102 & 173 & 114 & 201 \\
\hline$s_{\mathrm{x}}$ & 10 & 51 & 12 & - & - & 93 \\
\hline $\begin{array}{l}\% \text { difference } \\
\text { to group } 1\end{array}$ & & $+66 * *$ & $+57^{* * *}$ & +166 & +75 & $+209 * * *$ \\
\hline \multicolumn{7}{|c|}{ (c) Small nerve cells/I large nerve cell } \\
\hline $\bar{x}$ & 175 & 118 & 93 & 55 & 69 & 40 \\
\hline $\begin{array}{l}s_{\mathrm{x}} \\
\% \text { difference }\end{array}$ & 34 & 71 & 11 & - & - & 16 \\
\hline to group 1 & & -32 & $-47^{* * \bullet}$ & -69 & -60 & $-77 * * *$ \\
\hline
\end{tabular}

TABLE 3

STRIATUM - ABSOLUTE NUMBER OF SMALL NERVE CELLS AND GLIAL CELLS (10 cells)

\begin{tabular}{|c|c|c|c|c|c|c|c|c|c|}
\hline \multirow[t]{2}{*}{ Case group } & \multicolumn{2}{|l|}{1} & \multirow{2}{*}{$\begin{array}{l}2 \\
\text { q }\end{array}$} & \multicolumn{2}{|l|}{3} & \multirow{2}{*}{$\begin{array}{l}\text { Bu } 11 \\
\uparrow\end{array}$} & \multirow{2}{*}{$\begin{array}{l}4 \\
\text { 우 }\end{array}$} & \multicolumn{2}{|l|}{5} \\
\hline & ఠ & 우 & & 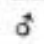 & 우 & & & $\delta$ & 우 \\
\hline
\end{tabular}

(a) Small nerve cells

\begin{tabular}{lrrrrrrrrr}
$n$ & 10 & 4 & 2 & 1 & 4 & 1 & 1 & 1 & 5 \\
$\bar{x}$ & 110 & 105 & 96 & 103 & 85 & 31 & 53 & 21 & 32 \\
$s_{\mathrm{x}}$ & 22 & 9 & 0.6 & - & 15 & - & - & - & 9 \\
$\begin{array}{l}\% \text { difference } \\
\text { to group 1 }\end{array}$ & & & -9 & -6 & -19 & -70 & -50 & -81 & $-70 * * *$ \\
$\begin{array}{l}\text { (b) Glial cells } \\
\bar{x}\end{array}$ & 408 & 380 & 496 & 520 & 445 & 152 & 340 & 220 & 308 \\
$s_{\mathrm{x}} \begin{array}{c}\text { difference } \\
\text { to group 1 }\end{array}$ & 65 & 32 & 60 & - & 90 & - & - & - & 59 \\
\hline
\end{tabular}


TABLE 4

STRIATUM - VOLUMETRIC NERVE CELL DENSITY $(\%)$

\begin{tabular}{lllllll}
\hline Case group & 1 & 2 & 3 & Bu 11 & 4 & 5 \\
\hline$n$ & 15 & 2 & 5 & 1 & 1 & 6 \\
$\bar{x}$ & 4.06 & 3.26 & 3.26 & 2.76 & 3.46 & 2.92 \\
$s_{x}$ & 0.52 & 0.82 & 0.60 & - & - & 0.53 \\
$\%$ difference to group 1 & -20 & $-20 * *$ & -32 & -15 & $-28 * * *$ \\
\hline
\end{tabular}

TABLE 5

STRIATUM - ABSOLUTE VOLUME OF NERVE CELLS $\left(\mathrm{mm}^{3}\right)$

\begin{tabular}{|c|c|c|c|c|c|c|c|c|c|}
\hline \multirow[t]{2}{*}{ Case group } & \multicolumn{2}{|l|}{1} & \multirow{2}{*}{$\begin{array}{l}2 \\
9\end{array}$} & \multicolumn{2}{|l|}{3} & \multirow{2}{*}{$\begin{array}{l}\text { Bu } 11 \\
q\end{array}$} & \multirow{2}{*}{$\begin{array}{l}4 \\
9\end{array}$} & \multicolumn{2}{|l|}{5} \\
\hline & $\delta$ & 우 & & $\delta$ & 운 & & & oै & 우 \\
\hline$n$ & 10 & 4 & 2 & 1 & 4 & 1 & 1 & 1 & 5 \\
\hline$\hat{\boldsymbol{x}}$ & 423 & 374 & 295 & 420 & 274 & 91 & 234 & 121 & 121 \\
\hline$s_{x}$ & 112 & 45 & 117 & - & 22 & - & - & - & 37 \\
\hline \multicolumn{3}{|c|}{$\%$ difference to group 1} & -21 & -1 & $-27 * *$ & -76 & -37 & -71 & $-68 * * *$ \\
\hline
\end{tabular}

TABLE 6

STRIATUM - NUMERICAL GLIAL CELL DENSITY AND GLIAL INDEX

\begin{tabular}{|c|c|c|c|c|c|c|}
\hline Case group & 1 & 2 & 3 & Bu 11 & 4 & 5 \\
\hline \multicolumn{7}{|c|}{ (a) Numerical glial cell density $\left(10^{3}\right.$ cells $\left./ \mathrm{mm}^{3}\right)$} \\
\hline$n$ & 14 & 2 & 5 & 1 & 1 & 6 \\
\hline$\hat{\boldsymbol{x}}$ & 41.1 & 55.9 & 49.1 & 46.1 & 50.9 & 71.1 \\
\hline $5 \mathrm{x}$ & 4.7 & 1.9 & 4.8 & - & - & 12.8 \\
\hline$\%$ difference & group 1 & $+36 * * *$ & $+19 * *$ & +12 & +24 & $+73 * *$ \\
\hline \multicolumn{7}{|c|}{ (b) Glial index (glial cells/nerve cell) } \\
\hline$\hat{x}$ & 3.69 & 5.11 & 5.17 & 4.81 & 6.36 & 9.94 \\
\hline$s_{x}$ & 0.36 & 0.56 & 0.59 & - & - & 1.90 \\
\hline \multicolumn{2}{|c|}{$\%$ difference to group 1} & $+38 * * *$ & $+40^{* * *}$ & +30 & +72 & $+169 * * *$ \\
\hline
\end{tabular}

TABLE 7

PALLIDUM - FRESH VOLUME $\left(\mathrm{mm}^{3}\right)$

\begin{tabular}{|c|c|c|c|c|c|c|c|c|c|}
\hline \multirow[t]{2}{*}{ Case group } & \multicolumn{2}{|l|}{1} & \multirow{2}{*}{$\begin{array}{l}2 \\
9\end{array}$} & \multicolumn{2}{|l|}{3} & \multirow{2}{*}{$\begin{array}{l}\text { Bu } 11 \\
q\end{array}$} & \multirow{2}{*}{$\begin{array}{l}4 \\
9\end{array}$} & \multicolumn{2}{|l|}{5} \\
\hline & dै & \% & & ठै & 우 & & & $\delta$ & 운 \\
\hline \multicolumn{10}{|l|}{ (a) Lateral } \\
\hline$n$ & 10 & 4 & 4 & 1 & 4 & 2 & 1 & 1 & 6 \\
\hline $\bar{x}$ & 1220 & 1065 & 965 & 1365 & 1010 & 520 & 850 & 550 & 450 \\
\hline$s_{\mathrm{x}}$ & 142 & 181 & 56 & - & 240 & - & - & - & 71 \\
\hline \multicolumn{3}{|c|}{$\%$ difference to group 1} & $\rightarrow 9$ & +12 & -5 & -51 & -20 & -55 & $-58 * *$ \\
\hline \multicolumn{10}{|c|}{ (b) Medial } \\
\hline $\bar{x}$ & 520 & 430 & 350 & 470 & 410 & 230 & 405 & 260 & 215 \\
\hline$s_{\mathrm{x}}$ & 78 & 79 & 29 & - & 113 & - & - & - & 42 \\
\hline \multicolumn{3}{|c|}{$\%$ difference to group 1} & -19 & -10 & -5 & -47 & -6 & -50 & $-50 * *$ \\
\hline
\end{tabular}


TABLE 8

PALLIDUM - NUMERICAL NERVE CELL DENSITY (cells $/ \mathrm{mm}^{3}$ )

\begin{tabular}{|c|c|c|c|c|c|}
\hline Case group & 2 & 3 & Bu 11 & 4 & 5 \\
\hline \multicolumn{6}{|l|}{ (a) Lateral } \\
\hline 13 & 4 & 4 & 2 & 1 & 7 \\
\hline 437 & 452 & 357 & 423 & 365 & 621 \\
\hline $\begin{array}{ll}s_{\mathrm{x}} & 84\end{array}$ & 38 & 72 & - & - & 153 \\
\hline$\%$ difference to group 1 & +3 & -18 & -3 & -16 & $+42 * *$ \\
\hline \multicolumn{6}{|l|}{ (b) Medial } \\
\hline 327 & 362 & 263 & 352 & 283 & 414 \\
\hline $\begin{array}{ll}s_{\mathrm{x}} & 52\end{array}$ & 16 & 67 & - & - & 113 \\
\hline$\%$ difference to group 1 & +11 & -20 & +8 & -13 & $+27^{*}$ \\
\hline
\end{tabular}

\section{TABLE 9}

PALLIDUM - ABSOLUTE NUMBER OF NERVE CELLS (10 cells)

\begin{tabular}{|c|c|c|c|c|c|c|c|c|c|}
\hline \multirow[t]{2}{*}{ Case group } & \multicolumn{2}{|l|}{1} & \multirow{2}{*}{$\begin{array}{l}2 \\
9\end{array}$} & \multicolumn{2}{|l|}{3} & \multirow{2}{*}{$\underset{\substack{q \\
\text { Bu } 11}}{ }$} & \multirow{2}{*}{$\begin{array}{l}4 \\
q\end{array}$} & \multicolumn{2}{|l|}{5} \\
\hline & $\delta$ & 우 & & $\delta$ & 우 & & & $\delta$ & 우 \\
\hline
\end{tabular}

(a) Lateral

$\begin{array}{lrrrrrrrrr}n & 10 & 3 & 4 & 1 & 3 & 2 & 1 & 1 & 6 \\ \dot{x} & 540 & 465 & 432 & 360 & 398 & 217 & 309 & 480 & 262 \\ s_{\mathrm{x}} & 153 & 162 & 41 & - & 130 & - & - & - & 73 \\ \% & \text { difference to group 1 } & & -7 & -33 & -14 & -53 & -34 & -11 & -44^{*}\end{array}$

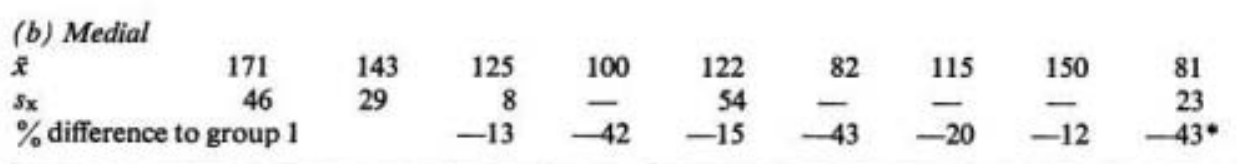

TABLE 10

PALLIDUM - VOLUMETRIC NERVE CELL DENSITY (\%)

\begin{tabular}{|c|c|c|c|c|c|c|}
\hline Case group & 1 & 2 & 3 & Bu 11 & 4 & 5 \\
\hline \multicolumn{7}{|l|}{ (a) Lateral } \\
\hline$n$ & 13 & 4 & 4 & 2 & 1 & 7 \\
\hline $\bar{x}$ & 0.36 & 0.32 & 0.31 & 0.42 & 0.24 & 0.54 \\
\hline$s_{\mathrm{x}}$ & 0.12 & 0.10 & 0.15 & - & - & 0.24 \\
\hline \multicolumn{2}{|c|}{$\%$ difference to group 1} & -11 & -14 & +17 & -33 & $+50^{*}$ \\
\hline \multicolumn{7}{|l|}{ (b) Medial } \\
\hline $\bar{x}$ & 0.31 & 0.30 & 0.21 & 0.36 & 0.32 & 0.41 \\
\hline$s_{\mathrm{x}}$ & 0.05 & 0.03 & 0.05 & - & - & 0.12 \\
\hline \multicolumn{2}{|c|}{$\%$ difference to group 1} & -3 & $-32 * *$ & +16 & +3 & +32 \\
\hline
\end{tabular}


TABLE 11

PALLIDUM - ABSOLUTE VOLUME OF NERVE CELLS $\left(\mathrm{mm}^{3}\right)$

\begin{tabular}{|c|c|c|c|c|c|c|c|c|c|}
\hline \multirow[t]{2}{*}{ Case group } & \multicolumn{2}{|l|}{1} & \multirow{2}{*}{$\begin{array}{l}2 \\
9\end{array}$} & \multicolumn{2}{|l|}{3} & \multirow{2}{*}{$\begin{array}{l}\text { Bu } 11 \\
\text { 우 }\end{array}$} & \multirow{2}{*}{$\begin{array}{l}4 \\
9\end{array}$} & \multicolumn{2}{|l|}{5} \\
\hline & $\delta$ & 우 & & $\delta$ & 우 & & & d & 우 \\
\hline
\end{tabular}

(a) Lateral

$\begin{array}{llllllllll}n & 10 & 3 & 4 & 1 & 3 & 2 & 1 & 1 & 6 \\ \hat{x} & 4.33 & 3.97 & 3.09 & 1.48 & 4.07 & 2.15 & 2.03 & 4.99 & 2.15 \\ s_{\mathrm{x}} & 1.90 & 1.22 & 0.90 & - & 0.99 & - & - & - & 0.98 \\ \% \text { difference to group } 1 & & -22 & -66 & +3 & -46 & -49 & +15 & -46^{*}\end{array}$

(b) Medial

$\begin{array}{lccccccccc}\hat{x} & 1.53 & 1.52 & 1.02 & 0.78 & 0.99 & 0.81 & 1.28 & 1.45 & 0.81 \\ s_{\mathrm{x}} & 0.30 & 0.51 & 0.08 & - & 0.50 & - & - & - & 0.28 \\ \% \text { difference to group 1 } & & -33 & -49 & -35 & -47 & -16 & -5 & -47^{*}\end{array}$

TABLE 12

PALLIDUM - NUMERICAL DENSITY OF GLIAL CELLS $\left(10^{3} \mathrm{cells} / \mathrm{mm}^{3}\right)$

\begin{tabular}{|c|c|c|c|c|c|c|}
\hline Case group & 1 & 2 & 3 & Bu 11 & 4 & 5 \\
\hline \multicolumn{7}{|l|}{ (a) Lateral } \\
\hline$n$ & 13 & 4 & 4 & 2 & 1 & 7 \\
\hline$\hat{x}$ & 66.3 & 95.5 & 68.5 & 92.7 & 98.6 & 147.7 \\
\hline$s_{\mathrm{x}}$ & 7.2 & 25.3 & 13.7 & - & - & 21.3 \\
\hline \multicolumn{2}{|c|}{$\%$ difference to group 1} & $+44^{\bullet \bullet}$ & +3 & +40 & +49 & $+123 \cdots \cdots$ \\
\hline \multicolumn{7}{|c|}{ (b) Medial } \\
\hline$\hat{x}$ & 62.1 & 81.7 & 62.2 & 93.7 & 68.7 & 113.7 \\
\hline$s \times$ & 7.4 & 13.8 & 15.8 & - & - & 14.8 \\
\hline \multicolumn{2}{|c|}{$\%$ difference to group 1} & $+31 * \bullet$ & \pm 0 & +51 & +11 & $+83 * * *$ \\
\hline
\end{tabular}

TABLE 13

PALLIDUM - ABSOLUTE NUMBER OF GLIAL CELLS $\left(10^{6}\right.$ cells)

\begin{tabular}{|c|c|c|c|c|c|c|c|c|c|}
\hline \multirow[t]{2}{*}{ Case group } & \multicolumn{2}{|l|}{1} & \multirow{2}{*}{$\begin{array}{l}2 \\
9\end{array}$} & \multicolumn{2}{|l|}{3} & \multirow{2}{*}{$\begin{array}{l}\text { Bu } 11 \\
\text { 우 }\end{array}$} & \multirow{2}{*}{$\begin{array}{l}4 \\
+\end{array}$} & \multicolumn{2}{|l|}{5} \\
\hline & $\sigma^{*}$ & 우 & & $\sigma^{*}$ & 우 & & & $\delta$ & 우 \\
\hline
\end{tabular}

(a) Lateral

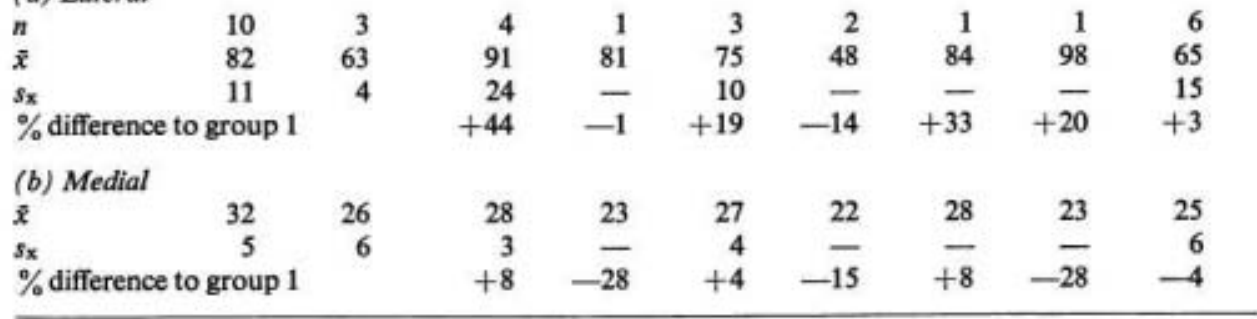


TABLE 14

PALLIDUM - VOLUMETRIC DENSITY OF GLIAL NUCLEI $(\%)$

\begin{tabular}{|c|c|c|c|c|c|c|}
\hline Case group & 1 & 2 & 3 & Bu 11 & 4 & 5 \\
\hline \multicolumn{7}{|l|}{ (a) Lateral } \\
\hline$n$ & 13 & 4 & 4 & 2 & 1 & 7 \\
\hline $\bar{x}$ & 0.43 & 0.50 & 0.59 & 0.55 & 0.69 & 0.68 \\
\hline$s_{\mathrm{x}}$ & 0.11 & 0.04 & 0.07 & - & - & 0.08 \\
\hline \multicolumn{2}{|c|}{$\%$ difference to group 1} & +16 & $+38^{*}$ & +28 & +60 & $+59 * \bullet *$ \\
\hline \multicolumn{7}{|l|}{ (b) Medial } \\
\hline$x$ & 0.43 & 0.45 & 0.46 & 0.44 & 0.49 & 0.50 \\
\hline \multirow{2}{*}{\multicolumn{2}{|c|}{$\%$ difference to group 1}} & 0.05 & 0.10 & - & - & 0.05 \\
\hline & & +5 & +7 & +2 & +14 & +16 \\
\hline
\end{tabular}

TABLE 15

PALLIDUM - ABSOLUTE VOLUME OF GLIAL NUCLEI (mm²)

\begin{tabular}{|c|c|c|c|c|c|c|c|c|c|}
\hline \multirow[t]{2}{*}{ Case group } & \multicolumn{2}{|l|}{1} & \multirow{2}{*}{$\begin{array}{l}2 \\
9\end{array}$} & \multicolumn{2}{|l|}{3} & \multirow{2}{*}{$\begin{array}{l}\text { Bu } 11 \\
\stackrel{9}{f}\end{array}$} & \multirow{2}{*}{$\begin{array}{l}4 \\
\$\end{array}$} & \multicolumn{2}{|l|}{5} \\
\hline & శే & q & & o & $q$ & & & $\delta$ & q \\
\hline
\end{tabular}

(a) Lateral

$\begin{array}{llllllllll}n & 10 & 3 & 4 & 1 & 3 & 2 & 1 & 1 & 6 \\ \vec{x} & 5.51 & 3.54 & 4.75 & 7.59 & 6.39 & 2.82 & 5.84 & 4.21 & 3.00 \\ s_{\mathrm{x}} & 1.55 & 0.79 & 0.37 & - & 0.63 & - & - & - & 0.61 \\ \% \text { difference to group 1 } & & +34^{*} & +38 & +81 * * & -20 & +65 & -21 & -15\end{array}$

(b) Medial

\begin{tabular}{lccccccccc}
$\hat{x}$ & 2.28 & 1.75 & 1.56 & 2.06 & 1.91 & 0.99 & 1.99 & 1.47 & 1.05 \\
$s_{\mathrm{x}}$ & 0.57 & 0.52 & 0.14 & - & 0.17 & - & - & - & 0.25 \\
$\%$ difference to group 1 & & -11 & -10 & +9 & -43 & +14 & -36 & $-40^{*}$ \\
\cline { 6 - 7 } & & & & & & &
\end{tabular}

TABLE 16

PALLIDUM - AVERAGE VOLUME OF GLIAL NUCLEI $\left(\mu \mathrm{m}^{3}\right)$

\begin{tabular}{|c|c|c|c|c|c|c|}
\hline Case group & 1 & 2 & 3 & Bu 11 & 4 & 5 \\
\hline \multicolumn{7}{|l|}{ (a) Lateral } \\
\hline$n$ & 13 & 4 & 4 & 2 & 1 & 7 \\
\hline$\hat{x}$ & 64.9 & 53.8 & 88.2 & 59.9 & 69.9 & 45.5 \\
\hline$s x$ & 18.5 & 8.6 & 12.6 & - & - & 3.1 \\
\hline \multicolumn{2}{|c|}{$\%$ difference to group 1} & -17 & $+36^{\circ}$ & -8 & +8 & $-30^{*}$ \\
\hline \multicolumn{7}{|c|}{ (b) Medial } \\
\hline $\bar{x}$ & 70.0 & 56.1 & 75.9 & 47.1 & 71.6 & 44.8 \\
\hline$s_{\mathrm{x}}$ & 17.6 & 6.4 & 16.2 & - & - & 8.3 \\
\hline \multicolumn{2}{|c|}{$\%$ difference to group 1} & -20 & +8 & -33 & +2 & $-36 * *$ \\
\hline
\end{tabular}


TABLE 17

PALLIDUM - GLIAL INDEX (glial cells/1 nerve cell)

\begin{tabular}{|c|c|c|c|c|c|}
\hline Case group & 2 & 3 & Bu 11 & 4 & 5 \\
\hline \multicolumn{6}{|l|}{ (a) Lateral } \\
\hline$n$ & 4 & 4 & 2 & 1 & 7 \\
\hline 158 & 209 & 197 & 219 & 270 & 253 \\
\hline$s_{\mathrm{x}} \quad 39$ & 36 & 52 & - & - & 80 \\
\hline$\%$ difference to group 1 & $+32^{*}$ & +25 & +39 & +71 & $+60^{* *}$ \\
\hline \multicolumn{6}{|l|}{ (b) Medial } \\
\hline $\begin{array}{ll}\bar{x} & 195\end{array}$ & 225 & 259 & 267 & 243 & 298 \\
\hline \multirow{2}{*}{$\begin{array}{l}s_{x} \\
\% \text { difference to group } 1\end{array}$} & 31 & 115 & - & - & 105 \\
\hline & +15 & +33 & +37 & +25 & $+53^{* *}$ \\
\hline
\end{tabular}

TABLE 18

NUCLEUS SUBTHALAMICUS

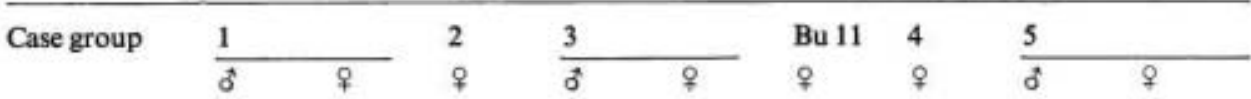

(a) Fresh volume $\left(\mathrm{mm}^{3}\right)$

$\begin{array}{lrrrrrrrrr}n & 10 & 4 & 4 & 1 & 4 & 2 & 1 & 1 & 6 \\ \hat{x} & 144 & 134 & 115 & 130 & 118 & 82 & 92 & 105 & 103 \\ s_{\mathrm{x}} & 19 & 14 & 7 & - & 28 & - & - & - & 10 \\ \% \text { difference to group 1 } & & -14 & -10 & -12 & -39 & -31 & -27 & -23 * *\end{array}$

\section{(b) Absolute number of nerve cells ( $10^{3}$ cells)}

$\begin{array}{lrrrrrrrrr}n & 11 & 3 & 4 & 1 & 3 & 2 & 1 & 1 & 5 \\ \bar{l} & 306 & 286 & 238 & 253 & 255 & 171 & 184 & 209 & 211 \\ s \times & 45 & 67 & 16 & - & 18 & - & - & - & 29 \\ \% \text { difference to group 1 } & & -17 & -17 & -11 & -40 & -36 & -32 & -26\end{array}$

(c) Absolute volume of nerve cells $\left(\mathrm{mm}^{3}\right)$

$\begin{array}{llllllllll}n & 10 & 3 & 4 & 1 & 3 & 2 & 1 & 1 & 5 \\ \bar{x} & 2.39 & 2.11 & 1.87 & 1.70 & 2.07 & 1.21 & 1.68 & 1.65 & 1.68 \\ s_{\mathrm{X}} & 0.68 & 0.29 & 0.12 & - & 0.27 & - & - & - & 0.41 \\ \% & \text { difference to group 1 } & & -11 & -29 & -2 & -43 & -20 & -31 & -20\end{array}$


without, however, reaching statistical significance. The lowest values were again found within the Huntington group (Table 18).

The average volumes of nerve cells were not significantly altered in the chorea group. The volumes have been determined by calculating the rotation ellipsoid volume after having measured the length and width of the cells as well as by the division volume cell density/numerical cell density.

\section{Correlations}

Normally the various parameters of the pallidum are more highly correlated with those of the putamen than with the parameters of the caudate nucleus. The correlation coefficients of striatum and pallidum laterale are higher than those of striatum and pallidum mediale. The diencephalic nuclei are better correlated with each other than with the striatum.

The pallidum laterale shows a better correlation with the subthalamic nucleus than does the pallidum mediale. An example of the strong correlation between the absolute number of nerve cells is shown in Fig. 4.

In the Huntington group the volume reduction of the striatum was significantly correlated with the shrinkage of the pallidum, but there was never any significant correlation between the nerve cell losses of the striatum and of the diencephalic nuclei nor between those of the pallidum and of the subthalamic nucleus.

\section{DISCUSSION}

\section{Subchorea}

Under this heading as well as under the name of "Status Subchoreaticus", Patzig $(1935,1939)$ described members of a family with slight involuntary movements in 5 generations. We have studied morphometrically 2 of these cases, in each case examining both hemispheres. The reduction of the volume of the striatum as described by Vogt and Vogt $(1937,1942)$ could not be confirmed. Brain weight, volumes of hemisphere, cortex, striatum, pallidum and subthalamic nucleus were not significantly reduced. The absolute number of nerve cells was found to be in the lower normal range. The absolute number of glial cells, however, was $30 \%$ greater in the striatum. In the pallidum laterale the increase of the absolute number of glial cells was $44 \%$. In the pallidum mediale the increase was slight and insignificant $(+4 \%)$. The increase of the absolute number of glial cells and the lack of a significant loss of nerve cells is also expressed by the glial index (number of glial cells per nerve cell), which is higher in the striatum $(+43 \%)$ as well as in the pallidum laterale $(+43 \%)$ and mediale $(+22 \%)$.

These findings are in sharp coritrast to those of the Huntington group in which severe loss of nerve cells and no increase in the absolute number of glial cells could be demonstrated.

From the morphological point of view Vogt's and Patzig's cases of subchorea cannot be regarded as a subunit of Huntington's chorea with less expressivity. This is not to say that in other cases with a late onset of the choreatic disease and minimal 
symptoms as described by Cornil, Waltrigny and Kissel (1929), Bruyn (1968), and others, such a variant of Huntington's chorea could not exist. One can only state that a neuropathological confirmation of such a variant is still lacking.

\section{Chorea minor}

The neuropathology of this disorder has not yet been established definitely as even severe forms may show a complete remission (Thiebaut 1968). Inflammatory and toxic-degenerative lesions have been described (Hallervorden 1957; Peters 1970).

We were able to study 5 cases morphometrically. Four of them will be discussed together, but the fifth needs special consideration because it showed softenings of the striatum. One of the 4 cases, suffering also from an endocarditis, died at the age of 11,3 years after the onset of the disease. The 3 others survived for 19-47 years after the period of chorea minor so that one could not expect to find acute pathological processes in the brain.

The volumes of the hemispheres, cortex, striatum, pallidum and subthalamic nucleus were not significantly diminished. The number of large nerve cells in the striatum was not reduced. Otherwise, irregular changes were found, mostly loss of nerve cells and gliosis. However, a severe loss of nerve cells was not regularly correlated with severe glial reactions. The reduction of the absolute number of small nerve cells in the striatum ranged from 5 to $20 \%$, the latter value only being significant. The mean diameter of the nuclei of the small nerve cells was found to be about $10 \%$ less compared with that of the control group. The reduction of the absolute number of nerve cells in the pallidum laterale ranged from $0 \%$ to $35 \%$, in the pallidum mediale from $0 \%$ to $50 \%$, in the subthalamic nucleus from $10 \%$ to $20 \%$. All cases showed an increase in the absolute number of glial cells in the striatum, ranging from $15 \%$ to $45 \%$. In 2 cases such an increase was also found in the pallidum laterale $(+20$ and $+35 \%$.

The conclusion based on these morphometric findings is that chorea minor is a polytopic process with varying afflictions of the striatum, pallidum, subthalamic nucleus and probably other regions, too.

Morphometrically this process is characterized by an increase in the number of glial cells and as a rule by a moderate loss of nerve cells.

Chorea gravidarum generally is regarded as a subgroup of chorea minor. Our case $\mathrm{Gr} 3$ had a more severe reduction of the absolute number of small nerve cells $(-40 \%)$ in the striatum than the other cases of chorea minor. The loss of nerve cells in the pallidum laterale and mediale amounted to $20 \%$. An increase of the number of glial cells was not apparent.

The special case $B u 11$ had chorea minor at the age of 16 . She died at the age of 64. Ischaemic softenings with similar topography but a different extent, due to atherosclerosis, were found in both caudate nuclei and putamina. The volume of the preserved tissue of the right striatum amounted to $35 \%$ and of the left striatum to $60 \%$ of the mean value of the control group. The absolute number of nerve and glial cells in the striatum was diminished by approximately the same percentage as the volume. The volume reduction of the pallidum laterale (left and right $-50 \%$ ) and of the 
pallidum mediale (left $-50 \%$, right $-40 \%$ ) as well as the decrease in the absolute number of nerve cells (lateral left $-55 \%$, right $-50 \%$; medial left $-45 \%$, right $-40 \%$ ) was not at all accentuated on the right side. The same holds true of the reduction of the volume and of the number of nerve cells in the subthalamic nucleus (left $-45 \%$ and $-50 \%$ respectively, right $-35 \%$ and $-30 \%$ respectively).

The softenings in the striatum on both sides were cystic. The glial reaction was still only slight; it was less pronounced on the right side.

Since the softening on the right side was much larger and probably older than that on the left side, the more severe loss of nerve cells in the left pallidum cannot be regarded as a purely transneuronal change.

\section{Atypical chorea}

Case Bu 42 is difficult to classify. Vogt and Vogt (1937) described it as praechorea, Hopf (1952) as a special form ("Sonderform") of chorea. Bruyn (1968), suggested that this case belonged perhaps to the category of subchorea. Bu 42 , however, showed choreiform movements since early childhood whereas subchorea manifests itself, as a rule, later in life. Heredity is missing in our case. This statement, however, is only based on unconfirmed data relative to the family history; members of the family were not examined.

Three cases of non-hereditary progressive chorea were described by Lewy (1923). Pathological alterations were found in the same regions as in Huntington's chorea. The changes in the striatum were considered to be comparatively slight. Alterations of the nerve cells of the pallidum could not be found whereas an increase of glial cells was observed.

Terplan (1924) published a non-hereditary case that had similar but less pronounced neuropathological alterations than his cases of Huntington's chorea.

According to Hopf (1952) the striatum of $\mathrm{Bu} 42$ was characterized by volume reduction, irregular density of the small nerve cells and slightly increased glial cell density. The putamen was considered to be more severely altered than the caudate.

Morphometrically, we found in $\mathrm{Bu} 42$ a $35 \%$ reduction in the volume of the putamen and a $15 \%$ reduction in that of the caudate. The numerical density of the small nerve cells was decreased by $30 \%$, the absolute number by $50 \%$. The numerical glial cell density showed an increase of $25 \%$, the absolute number a decrease of $10 \%$. In the pallidum laterale Hopf (1952) found smaller nerve cells, and a higher glial cell density, the latter being less accentuated in the pallidum mediale.

Morphometrically the numerical nerve cell density was only slightly reduced (by $15 \%$. The absolute number of nerve cells, however, was considerably reduced ( $35 \%$ lateral and $20 \%$ medial). The average volume of the nerve cells was diminished by $20 \%$ in the lateral part, this value being at the lower end of the normal range. The increase of the numerical glial cell density was found to be $50 \%$ in the pallidum laterale and $10 \%$ in the pallidum mediale. The gain in absolute number of glial cells was $33 \%$ lateral and $8 \%$ medial. There was a severe loss of nerve cells in the subthalamic nucleus $(-35 \%)$.

Thus the morphometric findings were similar to those observed in the Hunting- 
ton group, but they were less severe in the striatum and no atrophy of the cortex or the hemispheres had occurred. The process is considered to be multifocal.

Clinically and histologically there are some features that seem to justify a separation of this case from the Huntington group, as has been discussed in detail by Hopf (1952). The aetiology of this atypical form of chorea cannot be settled satisfactorily.

\section{Huntington's chorea}

In this group consisting of 6 cases the following average volume reductions were found: hemispheres and cortex $20 \%$, striatum $58 \%$, pallidum laterale $57 \%$, pallidum mediale $50 \%$ and subthalamic nucleus $24 \%$.

The shrinkage of the pallidum has been underestimated by many authors as Jungklaass and Orthner (1960) point out. It is as severe as that of the striatum. The same result was obtained by Orthner and Sendler (1975) who studied 106 human brains, including 58 "normal cases" and 10 cases of Huntington's chorea, by planimetric volumetry. The volume reduction of the subthalamic nucleus was often overlooked in the literature.

The numerical cell densities are of very limited value because they are affected by the shrinkage of the subcortical nuclei. The loss of small nerve cells in the striatum is more severe (absolute number about $-7 \%$ ) than the numerical density indicates (about $-35 \%$ ). Since there is no loss of large nerve cells, the ratio of large to small nerve cells, which is 1:175 in the normal group, changes to 1:40. Dom, Baro and Brucher (1973) found similar ratios of 1:145 in normal brains and 1:26 in Huntington's chorea.

The increase of the numerical cell density in the pallidum laterale and mediale (in our material $+42 \%$ and $+27 \%$, respectively) has led some authors to the erroneous statement that there was no loss or at least no considerable loss of nerve cells in the pallidum. In our Huntington material, the absolute number of nerve cells in both segments of the pallidum was about $40 \%$ lower than in the normal group. In the subthalamic nucleus the reduction was about $25 \%$.

The average volume of the nerve cells in the striatum, pallidum, and subthalamic nucleus was not significantly different from the normal group. Dom et al. (1973) were also unable to find any changes in the diameter of the small striatal cells in Huntington's chorea.

The average diameter of the nuclei of the small striatal nerve cells was significantly lower (by $20 \%, P \leqslant 0.01$ ) in our material. These small cells often had hyperchromatic nuclei.

The increase of the numerical density of glial cells in the striatum is a wellknown fact. In our material the percentage increase was $73 \%$. For the first time, however, it could be determined that the absolute number of glial cells did not increase in Huntington's chorea but decreased by up to $46 \%$. Only 1 of our cases had a normal number of glial cells.

Therefore the gliosis described by all the authors is not an absolute gliosis but only a relative one, caused by the shrinkage of the striatum. The number of glial cells per nerve cell, that is the so-called glial index, increased. It was calculated to be 
$3.69: 1$ in the normal group and 9.94:1 in the Huntington group $(+169 \%, P \leqslant 0.01)$. 9 The numerical density of the glial cells was significantly greater $(P \leq 0.01)$ in both segments of the pallidum, too, (lateral $+123 \%$, medial $+83 \%$ ). The mean of the absolute number of glial cells, however, was not significantly different from that of the normal group. But considerable interindividual variation was found in Huntington's chorea ranging from $+30 \%$ to $-40 \%$. Correlations with respect to age, onset and duration of the disease were not evident. The average volume of the glial cell nuclei was reduced by about $30 \%$. Whether or not this is due to a relative higher percentage of oligodendroglia can only be settled when counts of the different glial cell types have been completed.

Case C 14 which developed rigidity did not show any peculiarities as compared to the other cases.

On the basis of these morphometric data the question as to whether the process in the pallidum and subthalamic nucleus is a secondary, a transneuronal or a primary one should be reconsidered. It seems to be generally accepted that secondary changes in the pallidum exist in the form of a degeneration of striatal fibres. Gebbink (1968) has made special fibre studies confirming these findings.

The enormous shrinkage of the pallidum, however, can only be explained partially by this loss of striatal fibres. In this context one should take into consideration that the large striatal neurons are assumed to give origin to striatofugal fibres, whereas the small neurons are supposed to be exclusively Golgi II neurons with axonal endings within the striatum. Extensive Golgi and electron microscopic studies (Fox, Andrade, Hillman, and Schwyn 1971/1972; Fox, Andrade, Schwyn and Rafols, 1971/1972) could demonstrate that the myelinated striatal efferents to the pallidum originate in the large aspiny striatal neurons. The small spiny neurons were all found to be of Golgi II type. A loss of the large striatal neurons, however, did not exist in our material.

As long as the real extent of the shrinkage and particularly of the nerve cell loss of the pallidum was unknown, the supposition of transneuronal changes seemed reasonable. However, transneuronal atrophy or degeneration is a relatively rare phenomenon in adult mammalian brains compared to secondary or retrograde degeneration. This phenomenon has been most often described in the optic system, particularly in the lateral geniculate body. A prerequisite is a high-grade deafferentiation of nerve cells. The deafferented cells usually undergo atrophy and in severe cases they may also disappear. In our material the average volume of the pallidal nerve cells was not reduced, that is, they were not atrophied. The loss of nerve cells was very severe (about $-40 \%$ ). This would be a rather unusual effect of a very incomplete deafferentiation.

The pallidum gets its afferents from the striatum, the nucleus centromedialis thalami (Mettler 1945; Nauta and Whitlock 1954; Johnson 1961), the subthalamic nucleus (Whittier and Mettler 1949; Carpenter and Strominger 1967), the substantia nigra (Ranson and Ranson 1942; Fox and Schmitz 1944; Mettler 1948; Carpenter and McMasters 1964; Cole, Nauta and Mehler 1964; Mettler 1970), the nucleus ruber (Johnson and Clemente 1959), the nucleus interstitialis (Hassler 1956), and the lem- 
niscus medialis (Mettler 1945), whereas afferents from the cerebellum are not unchallenged (Mettler 1968) and those from the cortex are questionable (Truex and Carpenter 1969). Furthermore there are the afferents from the contralateral pallidum.

A loss of the large striatal nerve cells, from which the efferent fibres to the pallidum originate, could not be found. There are some indications that these large cells may also be affected in Huntington's chorea (see Hallervorden 1957; Bruyn 1968). However, they did not disappear during 8-18 years after the onset of the disease in our cases. Thus, it seems improbable that all axons of these cells degenerated and that the pallidum had no more striatal afferents. Only a partial loss of striatal fibres is probable. Most of the other structures that give origin to pallidal afferents were well- or relatively well-preserved. Most affected were the contralateral pallidum and the subthalamic nucleus but $60 \%$ and $75 \%$ of their neurons still persisted.

Certainly, transneuronal changes in the pallidum seem to be possible. In our opinion, however, the partial deafferentiation of the pallidum neurons cannot explain the severe nerve cell loss in this subcortical nucleus. Moreover the lack of correlation between the nerve cell losses in the striatum and in the pallidum argues against transneuronal degeneration. The supposition of transneuronal degeneration in the pallidum as a result of a lesion in the striatum is not confirmed either by experimental findings. After localized lesions in the striatum Cowan and Powell (1966) could not detect any atrophy or loss of nerve cells in the pallidum but only local gliosis. The pallidal nerve cell density increased. In those lesions large striatal nerve cells and their axons were destroyed as well, in contrast to the situation in Huntington's chorea.

The subthalamic nucleus obtains its main afferents from the pallidum laterale (Nauta and Mehler 1966), the contralateral subthalamic nucleus, the nucleus ruber (Carrea and Mettler 1954) and the cerebellum (von Monakow 1895; Orestano 1901). Thus the neurons of the subthalamic nucleus cannot be regarded as largely deafferented. In our opinion the nerve cell loss is mainly a primary one.

Our conclusion is that Huntington's chorea is a polytopic process. Cortex, striatum, pallidum, subthalamic nucleus and probably some other nuclei are the sites of the primary process in Huntington's chorea. These primary alterations are of course followed by secondary processes producing a very complex neuropathological picture.

The almost regular, severe impairment of the pallidum and the moderate impairment of the subthalamic nucleus should be taken into consideration in all pathophysiological theories attempting to explain chorea. Most theories seem to be limited too exclusively to the damage to the striatum.

In order to obtain a better insight into the nature of the pathological process, morphometric studies of relatively fresh cases of Huntington's chorea, more detailed studies of the large nerve cells in the striatum and special counts of the various types of glial cells would be helpful. 


\section{REFERENCES}

Blinkov, S. M. and I. I. Glezer (1968) The Human Brain in Figures and Tables, Basic Books, Inc., Plenum Press, New York, N.Y.

Bruyn, G. W. (1968) Huntington's chorea - Historical, clinical and laboratory synopsis. In: P. J. Vinken and G. W. Bruyn (Eds.), Handbook of Clinical Neurology, Vol. 6 (Diseases of the Basal Ganglia), North-Holland Publ. Comp., Amsterdam, pp. 298-378.

Carpenter, M. B. and R. E. McMasters (1964) Lesions of the substantia nigra in the rhesus monkey, Amer. J. Anat., 114: 293-319.

Carpenter, M. B. and N. L. Strominger (1967) Efferent fibers of the subthalamic nucleus in the monkey. - A comparison of the efferent projections of the subthalamic nucleus, substantia nigra and globus pallidus, Amer. J. Anat., 121: 41-72.

Carrea, R. M. E. and F. A. Mettler (1954) The anatomy of the primate brachium conjunctivum and associated structures, J. comp. Neurol., 101: 565-690.

Cole, M., W. J. H. Nauta and W. R. Mehler (1964) The ascending efferent projections of the substantia nigra, Trans. Amer. neurol. Ass., 89: 74-78.

Cornil, L., E. Waltrigny and P. Kissel (1929) Chorée chronique familiale à début tardif, Rev, neurol., 49: 369 .

Cowan, W. M. and T. P. S. Powell (1966) Strio-pallidal projection in the monkey, J. Neurol. Neurosurg. Psychiat, $29: 426-439$.

Dom, R., F. Baro and J. M. Brucher (1973) A cytometric study of the putamen in different types of Huntington's chorea. In: A. Barbeau, T. N. Chase and G. W. Paulson (Eds.), Advances in Neurology, Vol. 1, North-Holland Publ. Comp., Amsterdam, pp. 369-385.

Fox, C. A. and J. F. Schmitz (1944) The substantia nigra and the entopeduncular nucleus in the cat, J. comp. Neurol., 80: 323-334.

Fox, C. A., A. N. Andrade, D. E. Hillman and R. C. Schwyn (1971/72) The spiny neurons in the primate striatum. - A Golgi and electron microscopic study, J. Hirnforsch., 13: 181-201.

Fox, C. A., A. N. Andrade, R. C. Schwyn and J. A. Rafols (1971/72) The aspiny neurons and the glia in the primate striatum - A Golgi and electron microscopic study, J. Hirnforsch., 13: 343-362.

Gebbink, Th. B. (1968) Huntington's chorea. Fibre changes in the basal ganglia. In: P. J. Vinken and G. W. Bruyn (Eds.), Handbook of Clinical Neurology, Vol. 6 (Diseases of the Basal Ganglia), North-Holland Publ. Comp., Amsterdam, pp. 399-408.

Hallervorden, J. (1957) Huntington'sche Chorea (Chorea chronica progressiva hereditaria) - Chorea minor, Chorea gravidarum, senile Chorea und andere Choreaformen. In: O. Lubarsch, H. Henke und R. Rössle (Eds.), Handbuch der speziellen pathologischen Anatomie und Histologie, Vol. 13, Part 1A, Springer-Verlag, Berlin, Göttingen, Heidelberg, pp. 793-835.

Hassler, R. (1956) Die extrapyramidalen Rindensysteme und die zentrale Regelung der Motorik, Dtsch. Z. Nervenheilk., 175: 233-258.

Haug, H. (1955) Die Treffermethode, ein Verfahren zur quantitativen Analyse im histologischen Schnitt, Z. Anat. Entwickl.-Gesch., 118: 302-312.

Haug, H. (1967) Probleme und Methoden der Strukturzählung im Schnittpräparat. In: E. R. Weibel and M. Elias (Eds.), Quantitative Methoden in der Morphologie, Springer-Verlag, Berlin, pp. 58-78.

Hopf, A. (1952) Uber eine patho-anatomische Sonderform der Chorea, J. nerv. ment. Dis., 116: 608-618.

Johnson, T. N. (1961) Fiber connections between the dorsal thalamus and the corpus striatum in the cat, Exp. Neurol., 3: 556-569.

Johnson, T. N. and C. D. Clemente (1959) An experimental study of the fiber connections between the putamen, globus pallidus, ventral thalamus and midbrain tegmentum in the cat, $J$. comp. Neurol., 113: 83-101.

Jungklaass, F. K., and H. Orthner (1960) Uber quantitative Beziehungen im Stammhirn, Dtsch. $Z$. Nervenheilk., 181: 62-70.

Kretschmann, H.-J. and F. Wingert (1969) Biometrische Analyse der Volumina des Striatum einer ontogenetischen Reihe von Albinomāusen, Z. Anat. Entwickl.-Gesch., 128: 85-108.

Lange, H. und G. Thörner (1974) Zur Neuroanatomie und Neuropathologie des Corpus striatum, Globus pallidus und Nucleus subthalamicus beim Menschen, Thesis, Düsseldorf.

Lange, H., G. Thörner and A. Hopf (1976) Morphometrisch-statistische Strukturanalysen des Stria- 
tum, Pallidum und Nucleus subthalamicus beim Menschen, Teil 3 (Nucleus subthalamicus), J. Hirnforsch., 17: $\mathrm{Hl}$, in press.

Lewy, P. H. (1923) Die Histopathologie der choreatischen Erkrankungen, Z. ges. Neurol. Psychiat., 85: 622-635.

Mettler, F. A. (1945) Fiber connections of the corpus striatum of the monkey and baboon, J. comp. Neurol., 82: 169-204.

Mettler, F. A. (1948) Neuroanatomy, The C. V. Mosby Company, St. Louis, Miss.

Mettler, F. A. (1968) Anatomy of the basal ganglia. In: P. J. Vinken and G. W. Bruyn (Eds.), Handbook of Clinical Neurology, Vol. 6 (Diseases of the Basal Ganglia), North-Holland Publ. Comp., Amsterdam, pp. 1-55.

Mettler, F. A. (1970) Nigrofugal connections in the primate brain, J. comp. Neurol., 138: 291-320.

Monakow, C. von (1895) Experimentelle und pathologisch-anatomische Untersuchungen über die Haubenregion, den Sehhügel und die Regio subthalamica, nebst Beiträgen zur Kenntnis früh erworbener Gross- und Kleinhirndefecte, Arch. Psychiat. Nervenkr., 27: 1-128, 386-478.

Nauta, W. J. H. and W. R. Mehler (1966) Projections of the lentiform nucleus in the monkey, Brain Res., 1:3-62.

Nauta, W. J. H. and D. G. Whitlock (1954) An anatomical analysis of the nonspecific thalamic projection system. In: E. D. Adrian, F. Bremer and H. J. Jasper (Eds.), Brain Mechanisms and Consciousness, Blackwell Scientific Publications, Oxford, pp. 81-116.

Orestano, F. (1901), Le vie cerebellari efferenti - Contributo sperimentale anatomo-fisiologico, Riv. Pat, nerv. Ment., 6: 49-69.

Orthner, H. and W. Sendler (1975) Planimetrische Volumetrie an menschlichen Gehirnen, Fortschr. Nenrol. Psychiat., 43: 191-209.

Patzig, B. (1935) Vererbung von Bewegungsstörungen, Z. indukt. Abstamm.- u. Vererb.-Lehre, 70: 476.

Patzig, B. (1939) Erbbiologie und Erbpathologie des Gehirns. In: G. Just (Ed.) Handbuch der Erbbiologie des Menschen, Vol. 5, Part 1, Springer-Verlag, Berlin, pp. 233-349.

Peters, G. (1970) Klinische Neuropathologie, Thieme Verlag, Stuttgart.

Ranson, S. W. and S. W. Ranson, Jr. (1942) Efferent fibers of the corpus striatum, Res. publ. Ass. nerv, ment. Dis., 21: 69-76.

Schröder, K. F., A. Hopf, H. Lange and G. Thörner (1975) Morphometrisch-statistische Strukturanalysen des Striatum, Pallidum und Nucleus subthalamicus beim Menschen, Teil 1 (Striatum), J. Hirnforsch., 16: 333-350.

Stephan, N. (1960) Methodische Studien ũber den quantitativen Vergleich architektonischer Struktureinheiten des Gehirns, Z. wiss. Zool., 164: 143-173.

Terplan, K. (1924) Zur pathologischen Anatomie der chronischen progressiven Chorea, Virchow's Arch. path. Anat., 252: 146-176.

Thiebaut, F. (1968) Sydenham's Chorea. In: P. J. Vinken and G. W. Bruyn (Eds.), Handbook of Clinical Neurology, Vol. 6 (Diseases of the Basal Ganglia), North-Holland Publ. Comp., Amsterdam, pp. 409-434.

Thörner, G., H. Lange and A. Hopf (1975) Morphometrisch-statistische Strukturanalysen des Striatum, Pallidum und Nucleus subthalamicus beim Menschen, Teil 2 (Pallidum), J. Hirnforsch., 16: 403-415.

Truex, R. C. and M. B. Carpenter (1969) Human Neuroanatomy, The Williams and Wilkins Company, Baltimore, Md.

Vogt, C. and O. Vogt (1937) Sitz und Wesen der Krankheiten im Lichte der topischen Hirnforschung und des Variierens der Tiere, Vol. 1, J. A. Barth Verlag, Leipzig.

Vogt, C. and O. Vogt (1942) Morphologische Gestaltungen unter normalen und pathogenen Bedingungen, J. Psychol. Neurol., 50: 161-525.

Vogt, O. (1940) Uber nationale Hirnforschungsinstitute, J. Psychol. Neurol., 50: 1-10.

Whittier, J. R. and F. A. Mettler (1949) Studies on the subthalamus of the Rhesus monkey, J. comp. Neurol., 90: 281-317. 